\title{
PROGRESS TOWARDS THE IMPLEMENTATION OF THE PRME: LESSONS FROM A SOUTH AFRICAN BUSINESS SCHOOL
}

\author{
N. D. Baloyi \\ Department of Public Administration and Management \\ University of South Africa \\ Pretoria, South Africa \\ e-mail: ebaloynd@unisa.ac.za \\ D. de Jongh \\ Department of Business Management \\ University of Pretoria \\ Pretoria, South Africa \\ e-mail: derick.dejongh@up.ac.za
}

\section{ABSTRACT}

One of the growing pillars addressing critical insights to management education is the United Nations' Principles for Responsible Management Education (PRME). This article follows on a study conducted on a South African business school's experience with the PRME as a mechanism to transform business education. Apart from tracking progress regarding PRME, the study also aimed to identify the South African grasp of a transforming management education. In-depth interviews were conducted on the school's members of faculty who are responsible for tuition and curriculum development. Following analysis of the data, the study found that indeed the PRME initiative is globally relevant and recognised, and has paved the way for hundreds of business schools to start thinking about their curricula. From the single-case inquiry, the study concludes that the case school has made progress concerning systemic integration of the PRME into its curriculum. However, the study also found that fundamental challenges exist, confronting both Business Schools and the PRME in general. Inconsistent communication on progress and lack of integrating PRME into research mandate were found to be among the leading reasons why PRME implementation has not been successful.

Keywords: PRME, management education, implementation, business school, sustainable development, curriculum

\section{INTRODUCTION}

There is currently no other evidence of a formal study being done on an SA Business School's experience in signing up to the PRME. It therefore is uncertain to what extent signing up to the PRME has had any significant impact on the curriculum, research mandate and overall strategy and operations of business schools in South Africa (SA). Without such empirical evidence, it 
would be premature to argue that the PRME has had either positive or negative consequences. SA is a country with a complex history of socio economic and pluralistic challenges. The role of the business sector in contributing towards a new democratic dispensation in 1994 and addressing these challenges has never been questioned. Business schools, being providers of postgraduate students in business and management, play a critical role in preparing managers to understand their role in building a democratic SA. It is argued that examining the question of determining progress towards implementing the PRME principles in a SA business school is needed, relevant and timely.

The PRME were launched in 2007 by the United Nations Global Compact. This was an initiative aimed at providing a benchmark for the transformation of management education globally. The PRME are guiding principles to institutions/schools of management education regarding matters of sustainable development and corporate responsibility. Over the past few decades, the United Nations (UN) has led global discussions on sustainability. However, the paramount focus of the said discussions has been on environmental and economic sustainability - with particular reference to the adverse reaction by the natural environment to industrial and technological developments. In addition, most global economies are still in the recovery phase following the global economic meltdown of 2008 (Dickson et al. 2013, 311). Among other causes, this was a prelude to the UN's deciding to initiate discussions and debates over sustainability in management education, which later resulted in the formation of the PRME. The PRME comprises six comprehensive principles, namely: purpose, values, method, research, partnership and dialogue (PRME 2007).

Apart from serving as guidance to business schools, a subsequent aim of the PRME was to raise global awareness of the importance of conscious learning within management education institutions. The efforts of the UN, particularly in the context of the PRME, have been widely supported and accepted across the world, and their objectives seem to be welcomed by the organisations that have signed up to the PRME. The PRME work on a signatory basis, where interested organisations sign up as an agreement to incorporate the vision of the PRME in their curriculum offerings. In August of 2013, there were 506 organisations that had signed up to support the UN vision through implementation of the PRME (Nhamo and Nhamo 2014, 94). By the middle of 2015, PRME signatory institutions had grown to 601 signatories (PRME 2015).

In terms of South African business schools, by June of 2016, nine business schools had signed up to support the PRME initiative. The universities of Stellenbosch, Pretoria (Gordon Institute of Business Science), Cape Town, Rhodes, Nelson Mandela Metropolitan, and KwaZulu-Natal were the formal universities to sign up. Private institutions like Milpark 
Business School, Regenesys and MANCOSA were also participating (PRME 2016). In 2018, the number of signatories in SA has increased to eleven business schools, while other African signatories have also emerged - five in Morocco, four in Nigeria, six in Egypt and one for Ghana, Kenya and Tanzania (PRME 2018).

Roughly over a decade since the PRME were formed, the number of signatories to the PRME have been increasing at a satisfactory rate. In June 2018, there were 697 institutions that had signed up (PRME 2018). There is, however, potential for further growth in these numbers, given that the current signatories only represent a tip of the iceberg in terms of business school numbers globally. Having noted that, strong motivation is needed for other business schools as to why they should support PRME. PRME has become the largest organised relationship that the UN has had with management-related academic institutions (Haertle et al. 2017, 66). This article presents the findings of an empirical study conducted on a South African business school, to track progress made towards the implementation of the PRME. The overall contribution of the study was predominantly on improving the practices of implementing the PRME, including suggestions on dealing with the main challenges linked to the process.

\section{CONTEXT, OVERVIEW AND RATIONALE}

As part of achieving its main purpose, which was to track the progress made towards the implementation of the PRME, the study focused on only one of the above-mentioned South African business schools. The reason for selecting that particular school was its PRME status as a communicating participant at the time of the study (2016). The PRME differentiates between communicating, non-communicating and champion participants, based on the school's interaction with the PRME secretariat and adherence to signatory requirements. The case school has since been elevated to PRME champion in 2018, which indicates an advanced status. The case school offers business-specific programmes that typical business schools offer, from postgraduate diplomas to the $\mathrm{PhD}$.

This study was undertaken to track the progress made by a signatory school in terms of PRME implementation, and is suggested to be a relevant area of investigation (Alcaraz, Marcinkowska and Thiruvattal 2011, 151). Morsing and Rovira (2011) and Moratis $(2013,139)$ argue that there is some role that business schools can play, particularly in society. They also claim that should business schools be successful in the objective of helping both society and business to flourish, it could serve as a standard by which future leaders can manage their organisations.

The purpose of this research is to spread the PRME message, while encouraging more schools of management education to reflect and consider whether or not the PRME is something 
they would want to associate with. The nobility of the principles has been affirmed by various institutions globally that have adopted them (Cooper, Parkes and Blewitt 2014, 235-237). Prior to this research, a study of this nature had not been conducted in South Africa to track the progress of PRME implementation through a signatory institution (Nhamo and Nhamo 2014, 95).

The PRME are, by some measure, a positive stride in attempting to improve management education. However, their nature as mere best-practice guidelines with no power of enforcement suggests that the avenue for challenges co-exists with the possibility of success. One key challenge, which encapsulates the wider problem of this research, are the interactive complexities linked to implementing the PRME. This can be likened to some of the complexities which confronted the Millennium Development Goals (MDGs). The MDGs were launched in 2000 by the UN and their objectives were set to be realised by 2015 . Towards the end of the first half of 2016, when the study was being concluded, there was much room for progress towards those goals to still be improved, especially on the African continent.

The PRME have a similar trait, as they are a future-oriented sustainability initiative. Should the PRME have a chance to be more successful than other programmes of the UN, the implication is for monitoring and peer learning to be practised by both the PRME Secretariat and signatory schools. The assumption brought forward here is that there must have been some motivating factors that drove business schools to sign up to PRME, and this article presents some of the reasons or drivers, in the specific experiences of the case school for the study. In addition, the research also investigated how the participation with the PRME affected the school in terms of strategy and operational implementation.

\section{THEORETICAL PERSPECTIVES}

This section presents an overview of the management education literature and the PRME.

\section{Overview of management education}

One of the earliest publications on management education can be tracked back to the writings of Richardson (1940), when he reported on evidence of a programme focusing on estate management offered in the fourteenth century by Oxford University (Spender 2005, 1284). Other traces of earlier writings led to the works of Fritz Redlich (1957) focusing on the German evolution of management education. It is from the point of these traces that Hatch, Kostera and Kozminski (2005) referred to management education as a reservoir from which numerous disciplines were created. Management education almost acted as a link between those who studied it and the real situation in which they found themselves. This link brought about the 
interaction that saw the evolution of various disciplines like economics, human resources, finance and business education (Wedlin 2010 208). This is supported by Hallinger and $\mathrm{Lu}$ (2011, 279-281), in their similar argument that the founding principles of management education were borrowed from existing disciplines from before the nineteenth century. Management education has since developed to include doctrines and theories from various disciplines (Xie and Steiner 2013).

Starkey and Tempest (2009) point out that the discourse on management education was for the benefit of business schools, and this provided a shaping of business education pedagogy. To this effect, they support the idea that business schools had to undergo a paradigm shift after World War II. Part of this paradigm shift included reforms on discipline-based scholarship and methodological rigour in terms of how they offer their programmes (Starkey and Tempest 2009).

Traditionally, management education did not focus on the sustainable development of either business or society (Fisher and Bonn 2017). Various scholars agree that it focused mainly on teaching business students and executives about various ways of operating business with the end goal of maximising profit, albeit at minimal financial loss (Bristow 2011; Kelley and Nahser 2013; Landrum and Ohsowski 2017).

However, there seems to be consensus over what the role of management education should be, particularly in society. Adombent, Fischer, Godemann, Herzig, Otte, Rieckmann and Timm (2014), Wals (2014), and Fisher and Bonn (2017) all argue that institutions of higher learning, like private businesses, have fallen behind and have not been held accountable for their social impact. The implication they bring forth is twofold, namely: the curriculum in business schools has not adequately prepared managers for the realities of society; and businesses have not subjected themselves to scrutiny and blame for societal and environmental problems.

Adombent et al. (2014) therefore argue that management education has to move towards facilitating reflection on the responsibility of individuals for the possible effects of their decisions and actions. Other views exist supporting this statement, notably those of Figueiro and Raufflet (2015), Von der Heidt and Lamberton (2014) and Godemann, Haertle, Herzig and Moon (2014) - that there is a lack of socio-economic focus in management education programmes, thereby creating a ripple effect on how business executives make decisions. In fact, the suggestion brought by the above authors is that management education should possibly be at the centre of business reform that would ultimately lead to a more sustainable and inclusive interaction between management education and society (Wu, Shen and Kuo 2015). 


\section{Criticisms of management education and the PRME}

The MBA is one of the programmes that allowed management education to gain prominence over decades; however, the strength and fame of the MBA could not save management education from the criticisms that would later confront it. A few authors claim that the criticisms of management education centre around three fundamental questions, namely: What are students learning; What kind of learning is it; and What type of students enrol at business schools? (Dyllick 2015, 17; Haski-Leventhal 2014, 29).

These questions provide the platform for multi-faceted inquiries as to the relevance of management education in a changing society. The criticisms served as a wakeup call to reevaluate traditional methods of business education, shifting towards a more socially inclusive pedagogical structure. The focus of these criticisms was to advocate for the transformation of student knowledge and values, so that students could gain the knowledge and skills needed in real-life business scenarios (Grey 2005, 180).

The criticisms meant there was a need to draw up a response in order to resuscitate the relevance of management education, and to give it a societal standing. The responses had to provide solutions that would deal with potential improvements to the offerings of business schools and the delivery thereof (Xie and Steiner 2013,4). One such response came in the form of critical management education, which provided students with the opportunity to question traditional methods of business practice and education (Rabasso and Rabasso 2010, 67). Questions of value started to arise. For whom do business schools create value? The basis of this question forms one of the reasons why management education was heavily criticised (Strachowics-Stanusch 2011, 163).

The emergence of responsible management education was a result of such criticisms. Advocacy for responsibility in management education has been on the agenda for almost 40 years (Harney and Thomas 2013, 511). Initiatives have also emerged responding to the call of responsible management education, more notably business teachings that have started to include the role of business in society. Among other responses was the establishment of the Principles for Responsible Management Education (Cornuel and Hommel 2015, 3).

\section{The Principles for Responsible Management Education (PRME)}

As briefly mentioned earlier, the PRME were developed by the United Nations Global Compact (UNGC), responding to multi-sector pressures exerted by society on business and subsequently on the role of business schools in broader society. The principles also aimed to address concerns over how sustainable development could be achieved in business education. The PRME offer a futuristic aspiration that can create value in both society and business so that leaders can 
address difficult contemporary challenges faced by the socio-economic environment (Moratis 2013, 139; Verbos 2016, 11). Dickson et al. $(2013,309)$ shared a similar observation in their views concerning the principles. They argue that crises such as energy shortfalls, corporate scandals, global financial crises and food shortages have paved the way for critical inquiries on management education.

A study by Dickson et al. $(2013,310)$, on a model for sustainable development in education, highlights how some business schools in the United States partnered in developing educational programmes on social responsibility and sustainability. They further relay that peer learning between institutions could strengthen the drive towards a more sustainable management education. The PRME offer an opportunity for business schools to show their commitment to transform management education towards being both sustainability-driven and having societal relevance (Waddock et al. 2011).

The important critique that paved the way for stronger debates regarding the PRME, however, emanated from management executives who believed in initiatives like the PRME. The question seems to be more about what is being done by management educators and business schools to assist business executives to learn what is necessary to prepare them for a future characterised by complex socio-economic challenges (Gitsham 2011, 501). According to Alcaraz et al. (2011), the PRME may therefore be viewed as an imminent call for business schools to re-evaluate their provision and delivery of management education. Rasche, Gilbert and Schedel $(2013,72)$ support this view by stating that the PRME "should be viewed as one of the possible ways to create a strategic approach towards responsible management education." This, they feel, should transcend the barriers of isolated courses that speak to ethics in business.

$\mathrm{Wu}$, Shen and Kuo (2015) argue that the fundamental idea is for management education to adapt and move beyond the rhetoric of conventional models of management and business practices, which might be outdated considering the complex challenges business is faced with. According to Kelley and Nahser $(2013,634)$, sustainability and sustainable development are concepts that are constantly gaining wider recognition across various academic disciplines and industries. They further add that through the PRME, the UNGC initiated the drive towards sustainability and sustainable development in management education. However, while some scholars may, in view of the above PRME literature, support the objectives of the PRME, others believe that the PRME initiative can only develop if there is an emphasis on multi-stakeholder dialogue on the PRME and its objectives. Notably, Karakas, Sarigollu and Manisaligil (2013) highlight the importance of continued dialogue among business schools, businesses, government, civil society and global organisations like the UN. Although the PRME initiative is generally supported as an important movement to transform management education, it is not 
without fundamental critical inquiry. Prandini, Vervort and Barthelmess (2012) refer to the PRME as being defined on an abstract level, verifying this "abstractness" on two levels, namely: the implementation challenge faced by most signatory schools, and the complexity brought by the idea that schools needed to place emphasis on PRME integration. The level of "abstraction" poses a real risk for non-compliance simply because it could be seen as too aspirational and theoretical making it very difficult to achieve. Schuz (2012) supports the complexity of PRME, contending that the creation of a learning environment that accommodates the PRME (integration) would present a major challenge for many signatory schools. Furthermore, Kelly and Nahser (2013) claim that should the third principle of PRME (method) not be considered carefully, the first two principles (purpose and values) would not be possible. It once again directly points to the challenge of practical application of PRME which seems to be critiqued by many.

It is also worth noting that the PRME, being mere guidelines without any mandatory obligations nor any real non-compliance consequences, are also susceptible to failure with the possibility of not making any lasting impact on higher education, particularly in business schools. Perry and Win (2013) also mention the likelihood of such a failure with reference to other sustainable development related global interventions in higher education, and their subsequent failure to make a lasting impact, such as the Tblisi Declaration of 1997, the United Nations environment Programme (UNEP) and the Talloires Declaration. These interventions failed following a lack in the following areas: leadership commitment; knowledge on the declarations; sufficient time for implementation and sufficient involvement by staff and students (Walton 2000; Tallent and Shriberg 2003). Without calculated consideration to the points mentioned, the PRME cannot be successful, especially because it is voluntary in nature and lacks global visibility (Dyllick 2015). In addition to the impediments mentioned above confronting global interventions, the PRME has to battle against the financial justification that most institutions provide for not participating in voluntary interventions (Perry and Win 2013, 55). The PRME has included "dialogue" as the last of its six principles, under which is stated:

"We will facilitate and support dialogue and debate among educators, students, business, government, consumers, media, civil society organisations and other interested groups and stakeholders on critical issues related to global social responsibility and sustainability" (PRME 2018).

PRME signatory schools should therefore foster communicative action through various methods in order to achieve the objectives of the PRME. Having noted the argument earlier by Kelly and Nahser (2013) that principle three (method) was a condition for principles one and 
two (purpose and values), it is argued that principle 6 (dialogue), or communication, is equally crucial, without which most of the other principles would be difficult to achieve. Carvalho, Vitor, Cogo, Santos, and Ferreira Junior (2017) suggests that successful communication should have an element of sense, understanding and diversity. When the contrary (lack of sense, misunderstanding) occurs, which seems to be a real challenge for PRME signatory schools, chances of achieving these objectives would be very small. Carvalho et al (2017) also refers to the element of diversity which in the context of PRME could be seen as business schools' ability to communicate with a diverse set of stakeholders on issues related to PRME. There seems to be an inability amongst business schools to communicate issues around social responsibility and sustainability to external stakeholders which points towards the real challenge of integrating principle six of the PRME into business school operations. This once again supports the critique of PRME being too "abstract" in as much communication is concerned.

In light of the above discussion, this article supports the critical views that PRME is not beyond reproach. On the one hand, as pointed out also by (Herzig and Moon 2013), the many scandals in governance, financial crises and business' culpability in climate change point towards the failure of management education to reflect on ethical values, sustainable development and social responsibility as a core part of management curriculum. On the other hand, the PRME as a formalised way of sparking academic interest on sustainable development, present further complexity as these principles appear to be a vague articulation of certain competencies that business schools should have (Godemann et al. 2014). This is also indicated by the implementation challenge that most schools are faced with. Against this background, the study attempted to provide a link between what is known about PRME, how it works, why it exists, and the experiences of the case school.

\section{RESEARCH OBJECTIVES}

The research objective of the study was to gain an understanding of progress made towards the implementation of the PRME at the case school. More specifically, the objectives were:

- To provide an understanding of the case school's experience as a benchmark/reference point for those schools that have not yet signed up to PRME but have PRME aspirations

- To broaden the scope of knowledge regarding the PRME within higher learning institutions in South Africa.

In addition, the accompanying specific research objectives were: 
- To identify PRME-specific objectives at the case school

- To provide advocacy for responsibility in management education through critical discussions on the PRME

- To explore the possibility of extending PRME to university/college level.

\section{RESEARCH QUESTIONS}

The following research questions provided a gateway to collect data as part of achieving the general objective of the study

1. What progress has been made towards the implementation of the PRME at the school?

a. What were the drivers that encouraged the school to sign up to PRME?

b. Did the school wish to continue being a signatory to PRME?

c. Where there any challenges experienced in terms of PRME implementation?

2. Were there any consequences for the school's signing up to PRME in terms of:
a. Overall vision and strategy
b. Research and tuition
c. Implementation.

\section{RESEARCH DESIGN}

The methodological design of this research was qualitative, providing the most suitable approach to answer the research questions.

When selecting a sample for qualitative research, the strategy used must be suitable to enhance the understanding of the research problem, and should not follow the quantitative route of population representation (Kumar 2014). Selecting one business school as the case for this research is an appropriate strategy. The purpose of qualitative techniques is to address diversity. However, the possibility of data saturation exists, where very little to no new information can be gathered as the inquiry continues. This is even more prone to occur when data collected is done on a one-on-one basis (Leedy and Ormrod 2005, 145).

A purposive sampling technique was followed to make up the respondents that would provide the data. The application of this method meant that respondents could be intentionally selected based on the judgement of both the researcher and the key informant at the school who managed the school's sustainability programme. The sample comprised employees of the school of various ranks and expertise who were involved in tuition and also management. The sample was intentionally selected, based on the researcher's prior knowledge of what the 
sample could offer. The sample therefore did not provide a representation of the population as a whole, but a deliberate selection based on their likelihood of knowing about the school's activities towards PRME implementation.

The study applied the single-case design. The single-case design appeared logical, as the study investigated a single phenomenon, which was to track the progress made towards PRME. The selection of the school was motivated primarily by its keenness to participate actively in the PRME. At the time of the study, the school had been a signatory to PRME for seven years. The school has thus far been successful in submitting the required Sharing of Information on Progress (SIP) reports during its time as a signatory. As part of only eleven business schools in South Africa to sign up to the PRME, another indication that this was a good school to select is its current listing on the PRME website as a PRME champion in 2018 (a status given to signatories that adhere to the reporting requirement as set out by the PRME Secretariat). In addition, another motivation for the selection of this particular school was the school's commitment to its sustainability programme - that is, the school's eagerness to participate in global dialogues on sustainable development for business education, among its other sustainability-related activities.

The primary method of collecting data for this study was semi-structured interviews. Secondary sources were also used, such as the PRME reports by the case school and the PRME Secretariat. The analysis of secondary sources prior to the interviews also enhanced the level of engagement during data collection.

The entire research process for this study followed eleven phases from problem identification to presentation of results in the form of a research report, as set out in Table 1.

Table 1: the study-specific research process

\begin{tabular}{|c|l|}
\hline Phase & \multicolumn{1}{|c|}{ Activity } \\
\hline 1 & Problem identification question synthesis \\
\hline 2 & Selection of case school to carry out investigation \\
\hline 3 & Initial contact with informant to get familiar with case school \\
\hline 4 & Selection of a purposive sample based on expertise \\
\hline 5 & Compilation of interview schedule \\
\hline 6 & Validity check of questions - suitability for addressing phenomenon under study \\
\hline 7 & One-on-one semi-structured interviews conducted - 10 interviews \\
\hline 8 & Check if all interviews adhere to schedule and ethics requirements \\
\hline 9 & Recorded interviews transcribed \\
\hline 10 & Data analysis \\
\hline 11 & Collation of data and reporting of the results and findings \\
\hline
\end{tabular}




\section{Data analysis and evaluation}

In almost all cases, qualitative data comprise words and not numbers. As a result, the data needs to be broken down through analysis to bring order and understanding, firstly to the researcher and also to anyone who reads it (Powell and Renner 2003, 1). The discussions that took place during the interviews were recorded as raw data. This process was followed by a transcription of the recorded interviews. A thematic analysis was conducted in order to make sense of the data. From this analysis, themes and patterns were identified from the data. The aim of thematic analysis is to identify and capture the fundamental data that relates or is linked to the phenomenon under study (Braun and Clarke 2006, 79-82).

\section{RESULTS, FINDINGS AND DISCUSSION}

The results of the study were presented following the sequence of the sections that made up the interview schedule. To arrive at the final results, a logical and systematic process of thematic analysis was undertaken. The themes emerged from the raw data collected. The results, in sections, were as follows:

\section{Section 1 - General understanding of RME}

From the purposive sample of ten respondents, there was a general, satisfactory understanding of what responsible management education is about and the school's role in the delivery of management education. It was revealed in the study that most of the people at the school involved in tuition and management, particularly on the sustainability interface, were generally informed about what responsible management education is. That is, according to most respondents, that the tuition mandate in business schools must be the responsibility of individuals who have some expertise in what responsible management education is.

Sixty per cent of the sample reported that they had some kind of awareness of the PRME, while only half of that, 30 per cent of the entire sample, knew what the actual PRME are. From that 30 per cent who knew what the PRME are, only 10 per cent could actually list the principles. From the entire sample, 70 per cent of the respondents were in favour of the PRME as something the school should pursue. The remaining 30 per cent argued that in actual fact, the school was already living out all those PRME as a matter of everyday life.

A further question investigated whether, according to respondents' knowledge, the school had signed up to the PRME or not. Six $(60 \%)$ of the respondents knew that the school had signed up. Three (30\%) did not know, and one (10\%) assumed the school did sign up. These responses verified the findings of the preceding discussion in that there was a 60 per cent similarity in the respondents answering YES. Subsequent to that, a discussion ensued into their 
understanding of the school's efforts towards PRME implementation. In response, it was revealed that the principles were already a culture at the school.

In conclusion, Section 1 of the results showed that the sample understood the role of the school in providing responsible management education and that they are aware of existing efforts by the school to implement the PRME.

\section{Section 2 - Activities and plans of the school towards PRME implementation}

In the second section of the schedule, it was asked if the school actually provided responsible management education (RME). Eight (80\%) agreed with this, while the remaining two $(20 \%)$ highlighted the progressive steps the school was making towards strengthening its capacity to provide responsible management education. The study also revealed a unanimous echo on the emphasis of leadership support at the school regarding issues of sustainability and responsibility. It was also clear that there was a commitment on the part of the school's management to fully support the sustainability programme. There were also strong suggestions that the school had a stronger competitive advantage on the front of responsible management education in comparison with other schools in the country. It also emerged that reputation management was vital to the school and that it was in the best interests of the school to provide responsible management education.

Another key finding was that the school believed that its alumni were adequately prepared to exercise their roles as responsible business managers, as indicated by 80 per cent of the sample. Where MBA curriculum offerings at the school were concerned, all ten respondents were in agreement that their MBA programme taught modules that had a significant focus on business ethics and business responsibility. On the front of curriculum changes to the traditionally business-focused MBA programme, there was an indication that the MBA programme qualification mix had been changed on a few occasions since 2011, with the addition of modules on social responsibility and responsible leadership, among others.

The study also showed that members of faculty who were involved in the tuition aspect of the MBA programme were largely familiar with the school's being a signatory to the PRME (60\% of sample). However, 20 per cent of the sample were not certain if other lecturers knew, while the rest assumed that all members of faculty should be aware that the school was a PRME signatory.

In summary, Section 2 made it clear that the PRME message had been institutionalised at the school. In addition, it was also found that communication already existed among faculty members on some PRME-specific objectives, such as attempts to encourage research on social and developmental issues. Although most faculty members could not identify what the PRME 
are, it was revealed that the daily practices of the school were indeed linked to the PRME objectives. The implication of this is that the PRME were introduced into an environment where implementation could be possible. A general agreement among respondents, however, was that although some faculty members could not list the actual PRME, the school's already existing culture of collegial engagement provided a firm starting point to strengthen the PRME message.

\section{Section 3 - Challenges and the way forward}

\section{Challenges for the school}

In terms of challenges the school has experienced as a signatory to PRME, the following themes emerged: Integration (particularly integrating institutional strategy and curriculum content and the PRME objectives). Client responsiveness (businesses who ultimately would be employing MBA graduates from this school not showing much interest in PRME-related educational content). Research (business students showed little keenness to conduct research focused on socio-economic, environmental or PRME-related matters). Institutional delays (the school is an independent subsidiary of a university, where matters of curriculum and strategic changes must be approved by the parent university - which may take time). Curriculum integration came out as one of the paramount challenges for the school. Certain activities such as research advocacy and curriculum changes needed to be more streamlined and aligned to the PRME objectives of the school. Insofar as efforts to address the challenges were concerned, the following themes were identified: Leadership and support; curriculum review; topical emphasis; dialogue. The study revealed that support from the school's management/leadership structures made it possible to deal with challenges, particularly by appointing experts on the topic of sustainability in business education. There was also some evidence of efforts made towards improving dialogue: firstly on the rationale for sustainable development in business education, and more specifically on how the school could relay the PRME message to business students more effectively.

\section{Implications of joining PRME}

In terms of what the implications were for signing up to PRME, the study revealed the following themes: strategic alignment and everyday life (business as usual). There was a need for strategic alignment, which would in turn make it easier for the school to implement the PRME within its operational capacity. The implication for strategic alignment was that the school would need to reflect on its current methods of tuition and delivery; curriculum content; programme relevance; and student-centredness. The study also found that the school had 
experienced no undesired implications since signing up to PRME. However, there was also a common suggestion that there was much room for improvement for the school when it came to peer learning, where collaboration with other institutions is concerned, especially on PRME matters.

On the more reflective note regarding the PRME, the study found that members of staff were in favour of the PRME and its objectives. The following themes surfaced from that discussion: education; sustainability; necessity; good initiative. It was emphasised that for business to grow, education needs to continually take place with the future in mind, particularly on how business can strengthen its contribution to society. The study also revealed that the school found the PRME to be a necessary, progressive step in the right direction, particularly because it started to pave the way for critical reflection on the role of business in society.

\section{Has the school been successful in implementing the PRME?}

The study found that there was a positive attitude by the school towards the PRME, and that the school would be successful in reaching its PRME objectives and goals. During the few years that the school has been a signatory to PRME, stronger emphasis has been made on becoming a leading provider of responsible management education in South Africa. However, there were some muted concerns over the non-obligatory nature of PRME, particularly over the realistic possibility of PRME suffering the same fate of non-compliance as other standards of the United Nations.

Lastly, it was also found that there were three areas of improvement with regard to the school's attempts to implement the PRME: internal communication; integration of PRME into the school's research agenda; and participating in PRME peer learning opportunities.

\section{CONCLUSIONS}

The following case-specific conclusion is presented and placed in context with the literature in the broader field of responsible management education.

The study found evidence that pointed to a reasonable level of awareness among faculty members with regard to the meaning of responsible management education, particularly those who have a specific role to play in integrating the PRME into curriculum, as well as those who teach specific elements related to the PRME in the MBA programme. This finding supports evidence found in the literature that suggest for management education to transform beyond conventional methods and content, teachers of business education need to have a critical stance against management education curriculum and research mandates. They should also have fundamental knowledge of elements related to the PRME and be able to translate this into 
practical content delivery (Gitsham 2011). From the empirical inquiry followed in the study, it was also found that the school embraced the fundamental PRME requirement of communicating with the PRME Secretariat by means of submitting biennial progress reports. However, successes in PRME reporting were overshadowed by the school's inadequate internal communication regarding the PRME and its involvement in this initiative. Staff seemed to be uninformed and not really involved in the detail of what it means to be a signatory of the PRME.

A critical success factor towards the delivery of responsible management education is leadership commitment, or support from the management team of signatory schools (Perry and Win 2013, 65). It was revealed in the case school that although not overly visible, there was evidence of management support for the PRME initiative and for strengthening its sustainable development agenda through the provision of responsible management education. However, while the school's efforts indicate support for the PRME and its importance globally, some of the challenges that the school experienced, such as PRME integration, strategic alignment and research affinity suggest that the PRME must increase its footprint and strengthen support mechanisms for signatory schools.

The above study-specific conclusion presents a reflection of the literature that grounds this research, and also provide a few areas of discussion. In the first instance, the conclusions point toward a reflection that management education is a mere extension of existing ideologies and disciplines (Hallinger and Lu 2011; Xie and Steiner 2013). Secondly, they reveal the realities of what Adombent et al. (2014) and Pless and Maak (2011, 237-260 refer to as the inherent need for business educators and business executives alike to have some sort of awareness of the far-reaching consequences that their actions may have to society as a whole.

The importance of leadership cannot be overstated, as the above conclusions suggest. All signatories will require leadership commitment in order to successfully implement the PRME. Perry and Win $(2013,59)$ insist that the chances for failure in such initiatives are higher if the school's executives are not committed to the cause. Insofar as this is concerned, commitment by the case school's executives has led to the school's success in implementing the PRME.

The findings of this study point out that signatory schools can no longer just do business as usual, which is to conduct operations for the primary purpose of profit maximisation (Gitsham 2011, 502). There has to be a shift on the part of signatory schools to move from short-termism (profit driven) to long-term thinking (sustainable development), and by doing this equip students with the understanding of the transforming role of business in society (Baden and Parkes 2013, 296). This view is also supported by Escudero (2012, 35-38), who points out that the PRME exists to direct students and tuition managers towards a mind-set change, in terms of thinking more about the role of business in society. From the experiences of the case 
school, it was found that internal and external communication plays a major role in achieving strategic alignment with PRME objectives. There has to be continuous, multi-stakeholder dialogue if PRME is to be implemented successfully (Karakas et al. 2013, 804).

The study's conclusions also point out what existing literature describes as "research challenges aligned to PRME". There is little support for research areas linked to the objectives of PRME in business schools. As in the experiences of the case school, the research challenge is that most research in business schools never addresses social and environmental issues (Dyllick 2015, 22-25). Some literature suggests that this research challenge might be brought about by the assumption that business executives are merely concerned about maximising profit at minimal economic loss (Mukhi 2012, 57-59). Similar to this, (Davids and Waghid 2018) reflect on the importance of research, suggesting that research should be an indispensable pillar to teaching and learning. They further share similar views as in the specific findings of this study, that the teacher (faculty members in the case of business schools) should stimulate the student's desire to learn. This further adds to the PRME complexity, in that, the case school experienced challenges in channelling students to conduct PRME-related research, while also experiencing content delivery difficulties. The complexities linked to PRME are interactive in nature, i.e. poor communication, leading to inadequate strategies towards curriculum development; the lack of PRME attractiveness to students, leading to little keenness for student research on PRME matters; poor leadership commitment - leading to lethargic resource enforcement to support PRME-related initiatives and thereby creating an atmosphere of very little PRME visibility.

\section{GENERAL CONCLUSION}

While management education continues to transform, the pace of critical interventions towards this transformation remains somewhat slow. The PRME as an intervention is making small steps towards the improvement of dialogue on the role of business schools in society at large. This research is unique in that a similar study examining progress of the PRME in a South African business school has not been undertaken. The findings of this study reveal various aspects in terms of both strengths and weaknesses of the PRME. Above all, the study answered the research question "What progress has the case school made in terms of implementing the PRME?". The case school made progress in the following areas. Firstly, Strategic alignment to $P R M E$ - it takes some time and effort to realise strategic objectives of the PRME, notwithstanding the challenge of aligning business school operational objectives hereto. In this regard, the case school has made significant strides in simulating the PRME objectives through its operational strategies. Secondly, Adoption of the PRME vision - the case school has shown 
that it supports the PRME through the academic (mostly teaching) and operational activities that support the PRME. Thirdly, Actual progress - the school signed up in 2009, and has continued to submit the required progress reports by PRME. In 2016, the school was a communicating partner, while in 2018, it is listed as a PRME champion. This suggests that there is continuous progress made by the school towards the implementation of the PRME. Further research is suggested to determine what additional activities were implemented in support of the PRME since 2016, when this study was concluded, to enable the case school to occupy the position of a PRME champion in 2018.

The South African case for transforming management education still needs to build significant momentum. The socio-economic interface of South Africa is not exempt from the challenges brought about by the unclear role of business in society, hence the need for debates on the role of management education in this to be strengthened. Society can benefit from a transformed management education, as business executives, many of whom are alumni of business schools, become more aware of the crucial role that business must play in society. Although there is an existence of fundamental implementation challenges to PRME globally, the South African socio-economic landscape could benefit from business schools and higher education institutions who adopt sustainable development initiatives like the PRME. The lessons from this study should provide some much needed motivation for the PRME to continue its quest to transform management education not only within business schools but also in higher education in general.

\section{RECOMMENDATIONS AND CONSIDERATIONS}

The literature presented in this article emphasised the importance of continuous internal and external communication by PRME signatory schools in order to implement the PRME successfully. Internal and external communication on implementing the PRME was found to be the main challenge for the case school. The main recommendation for the case school is to improve on its efforts to strengthen communication regarding the PRME. On the one hand, improving internal communication on the PRME will benefit the school in various ways, including enhanced awareness of PRME by staff members; sharing of ideas on faculty level on how to integrate PRME objectives into the curriculum; and it could improve teacher-student engagement in terms of delivering content related to PRME. On the other hand, the school could also improve in terms of communicating externally, thereby ensuring that the business sector who employ MBA graduates understand the value and importance of PRME - they could look into the possibility of making being a PRME signatory a pre-requisite in employing MBA graduates from business schools. 
In the light of the main recommendation, the following supporting recommendations could also strengthen the school's PRME implementation efforts: improve PRME visibility (actual visuals of the PRME activities could be pasted on walkways, notice boards, canteen and lecture rooms); create platforms for student-centric PRME activities (this could encourage students to interact more on PRME-related initiatives) and include some PRME objectives to the research agenda by directing students to known PRME areas for possible research, and therefore influence students to think about empirical solutions to some PRME-related problems.

As much as the above discussion presents recommendations specifically for business schools, the findings also present some fundamental considerations for higher education in general. The literature indicates that at the centre of PRME is the intention to transform the role of business in society, through socially relevant business pedagogies. One of the objectives of the study was to explore the possibility of PRME extending to college/university level. In the current South African higher education interface, such an exploration is seemingly valuable. There is currently increasing pressure on institutions of higher learning in South Africa to develop relevant curricula content across various academic programmes. Most notably, the growing debate on the development of "decolonised" and "Africanised" educational content in order to adequately prepare graduates with the required skill-set to address $21^{\text {st }}$ century African problems. In view of this complex phenomenon, institutions of higher learning will have to ensure epistemological diversity through transformed pedagogical practices. Similar to the case of the PRME, if current challenges are to be mitigated, the higher education sector would also need to address the multi-factor challenge of leadership commitment; knowledge creation; staff/student involvement; effective communication and strengthening specific research agendas. This article insists that if PRME is to succeed in strengthening the sustainability agenda in higher education generally, it will have to address four implementation challenges identified by Leal-Fihlo (2011), namely: "firstly advocating for sustainability more widely than on ecological terms; secondly the need to interpret what 'added value' sustainability brings for various stakeholders; thirdly strengthening financial support and gain commitment from different stakeholders and finally creating solid projects that can demonstrate what can be achieved through integrating sustainable development initiatives into higher education".

Currently, the PRME does not seem to provide or define the skills, competencies and capacity needed for signatory institutions to successfully implement its objectives towards sustainable development. As such, strategic and operational uncertainty in this regard is easily foreseeable should the PRME be mainstreamed in institutions of higher education. However, this does not imply a rejection of the possibility of mainstreaming the PRME in higher education institutions. Considering human, financial and research capacity of most large 
universities, it is argued that meeting the PRME objectives could be achieved with relative ease. Therefore, even with the existence of fundamental challenges and critiques of the PRME, it is argued that the PRME could also find relevance in traditional universities, with the view of transforming curricula and research agendas in support of a sustainable future.

\section{NOTE}

*This article emanates from the primary author's masters dissertation entitled: Progress towards the implementation of the Principles for Responsible Management Education. The case of a South African business school.

\section{REFERENCES}

Adombent, M., D. Fischer, J. Godemann, C. Herzig, I. Otte, M. Rieckmann and J. M. Timm. 2014. Emerging areas in research on higher education for sustainable development - management education, sustainable consumption and perspectives from Central and Eastern Europe. Journal of Cleaner Production 61(1): 1-7.

Alcaraz, J. M., M. W. Marcinkowska and E. Thiruvattal. 2011. The UN-principles for responsible management education: Sharing (and evaluating) information on progress. Journal of Global Responsibility 2(2): 151-169.

Baden, D. and C. Parkes. 2013. Experiential learning: Inspiring the business leaders of tomorrow. Journal of Management Development 32(3): 295-308.

Braun, V. and V. Clarke. 2006. Using thematic analysis in psychology. Qualitative Research in Psychology 3(2): 77-101.

Bristow, R. 2011. Television discussion: The role of business schools in advancing sustainability. The Guardian. www.guardian.co.uk/sustainable-business/live-discussion-role-business-schoolssustainability (Accessed 25 July 2018).

Carvalho, D. P. S. R. P., A. F. Vitor, A.L. P. Cogo, V. E. P. Santos and M. A. Ferreira Júnior. 2017. Theory of communicative action: A basis for the development of critical thinking. Rev Bras Enferm 70(6): 1343-1346.

Cooper, S., C. Parkes and J. Blewitt. 2014. Can accreditation help a leopard change its spots? Social accountability and stakeholder engagement in business schools. Accounting, Auditing and Accountability Journal 27(2): 234-258.

Cornuel, E. and U. Hommel. 2015. Moving beyond the rhetoric of responsible management education. Journal of Management Development 34(1): 2-15.

Davids, N. and Y. Waghid. 2018. Prioritising higher education: Why research is all that matters. South African Journal of Higher Education 32(2): 1-7.

Dickson, M., M. Eckman, S. Loker and C. Jirousck. 2013. A model for sustainability education in support of the PRME. Journal of Management Development 32(3): 309-318.

Dyllick, T. 2015. Responsible management education for a sustainable world: The challenges for business schools. Journal of Management Development 34(1): 16-33.

Escudero, M. 2012. PRME in response to the global crisis. Speech delivered at a UNGC meeting, 3539.

Figueiro, P. S. and E. Raufflet. 2015. Sustainability in higher education: A systematic review with focus on management education. Journal of Cleaner Production 106: 22-23.

Fisher, J. and I. Bonn. 2017. Sustainability and undergraduate management curricula: Changes over a 5-year period. Australian Journal of Environmental Education 33(1): 18-33. 
Gitsham, M. 2011. CEO perspectives: Management education in a changing context. Corporate Governance 11(4): 501-512.

Godemann, J., J. Haertle, C. Herzig and J. Moon. 2014. United Nations-supported principles for responsible management education: Purpose, progress and prospects. Journal of Cleaner Production 62: 16-23.

Grey, C. 2005. Reinventing business schools: The contribution of critical management education. Academy of Management Learning and Education 3(2): 178-186.

Haertle, J., C. Parkes, A. Murray and R. Hayes. 2017. PRME: Building a global movement on responsible management education. International Journal of Management Education 15: 66-72.

Hallinger, P. and J. Lu. 2011. Assessing the instructional effectiveness of problem-based management education in Thailand: A longitudinal evaluation. Management Learning 42(3): 279-299.

Harney, S. and H. Thomas. 2013. Towards a liberal management education. Journal of Management Development 32(5): 508-524.

Haski-Leventhal, D. 2014. MBA student values, attitudes and behaviours: A cross-cultural comparison of PRME signatory schools. SAM Advanced Management Journal 79(4): 29-41.

Hatch, M. J., M. Kostera and K. Kozminski. 2005. The three faces of leadership: Manager, artist and priest. Malden, MA: Blackwell.

Herzig, C. and Moon, J. 2013. Discourses on corporate social ir/responsibility in the financial sector. Journal of Business Research 66(10): 1870-1880.

Karakas, F., E. Sarigollu and A. Manisaligil. 2013. The use of benevolent leadership development to advance principles of responsible management education. Journal of Management Development 32(8): 801-822.

Kelley, S. and R. Nahser. 2013. Developing sustainable strategies: Foundations, method, and pedagogy. Journal of Business Ethics 123: 631-644.

Kumar, R. 2014. Research methodology: A step by step guide for beginners. $4^{\text {th }}$ Edition. London: Sage.

Landrum, N. E. and B. Ohsowski. 2017. Content trends in sustainable business education: An analysis of introductory courses in the USA. International Journal of Sustainability in Higher Education 18(1): 385-414.

Leal-Fihlo, W. 2011. About the role of universities and their contribution to sustainable development. Higher Education Policy 24: 427-438.

Leedy, P. and J. E. Ormrod. 2005. Practical research: Planning and design. $8^{\text {th }}$ Edition. New Jersey: Pearson Prentice Hall.

Moratis, L. 2013. A tale of two standards on responsible management education. Journal of Global Responsibility 4(2): 138-156.

Morsing, M. and A. Rovira. 2011. Business schools and their contribution to society. London: Sage.

Mukhi, U. 2012. UN PRME and emerging economies. Research Paper, 56-59.

Nhamo, S. and G. Nhamo. 2014. Assessing progress in implementing the UN PRME: International perspectives and lessons from South Africa. Problems and Perspectives in Management 12(1): 94-108.

Perry, M. and S. Win. 2013. An evaluation of PRME's contribution to responsibility in higher education. New Zealand: Greenleaf.

Pless, N. and T. Maak. 2011. Developing responsible global leaders through international learning programs: The Ulysses experience. Academy of Management Learning and Education 10(2): 237260.

Powell, E. and M. Renner. 2003. Analyzing qualitative data (G3658-12): Program development and evaluation. Madison: University of Wisconsin.

Prandini, M., I. Vervort and P. Barthelmess. 2012. Responsible management education for 21st Century Leadership. Central European Business Review 1(2): 16-22. 
PRME see Principles for Responsible Management Education.

Principles for Responsible Management Education. 2007. The principles for responsible management education. www.unprme.org (Accessed 20 January 2015)

Principles for Responsible Management Education. 2015. The principles for responsible management education. www.unprme.org (Accessed 10 February 2015).

Principles for Responsible Management Education. 2016. About the principles. Principles for responsible management education. http://www.unprme.org/about-prme/the-six-principles.php (Accessed 10 May 2016).

Principles for Responsible Management Education. 2018. The principles for responsible management education. www.unprme.org (Accessed 18 June 2018).

Rabasso, C. and J. Rabasso. 2010. A Chomskyan approach to responsible management education. Journal of Global Responsibility 1(1): 66-84.

Rasche, A., D. Gilbert and I. Schedel. 2013. Cross-disciplinary ethics education in MBA programs: Rhetoric or reality? Academy of Management Learning \& Education 12(1): 71-85.

Redlich, F. 1957. Academic education for business: Its development and the contribution of Ignaz Jastrow. Business History Review 31: 35-91.

Richardson, H. G. 1940. Business training in Medieval Oxford. American History Review 46: 259-278.

Schuz, M. 2012. Sustainable corporate responsibility - The foundation of successful business in the new millennium. Central European Business Review 1(2).

Spender, J. C. 2005. Speaking about management education: Some history of the search for academic legitimacy and the ownership and control of management knowledge. Management Decision 43(10): 1282-1292.

Strachowicz-Stanusch, A. 2011. The impact of business education on students' moral competency: An exploratory study from Poland. Vision: The Journal of Business Perspective 15(2): 163-176.

Starkey, K. and S. Tempest. 2009. The winter of our discontent: The design challenge for business schools. Academy of Management Learning and Education 8: 576-586.

Tallent, H. and M. Shriberg. 2003. Beyond principles: Implementing the Talloires Declaration. www.ulsf.org (Accessed: 11 September 2015).

Verbos, A. K. 2016. Embedding the PRME in business law classes. Journal of Higher Education Theory and Practice 16(4): 11-24.

Von der Heidt, T. and G. Lamberton. 2014. How academics in undergraduate business programs at an Australian university view sustainability. Australian Journal of Environmental Education 30: 215-238.

Waddock, S., A. Rasche, P. Werhane and G. Unruh. 2011. The principles for responsible management education: Implications for implementation and assessment. In Got ethics? Toward assessing business ethics education, ed. D. Swanson and D. Fisher, 13-28. Charlotte, NC: Information Age.

Wals, A. E. J. 2014. Sustainability in higher education in the context of the UN DESD: A review of learning and institutionalisation processes. Journal of Cleaner Production 62: 8-15.

Walton, J. 2000. Should monitoring be compulsory within voluntary environmental agreements? Sustainable Development 8(3): 146-154.

Wedlin, L. 2010. Going global: Rankings as rhetorical devices to construct an international field of management education. Management Learning 42(2): 199-218.

Wu, Y. C., J. P. Shen and T. Kuo. 2015. An overview of management education for sustainability in Asia. International Journal of Sustainability in Higher Education 16(3): 341-353.

Xie, C. and S. D. Steiner. 2013. Enhancing management education relevance: Joint creation of knowledge between business schools and business. Business Education and Accreditation 5(2): $1-15$. 